\title{
Policy of Lampung Province Regional Budget Policy on Improving Performance of Health Fields: Lower Nutrition And Low Birth Weight Loss
}

\author{
Sutarto, Samsul Bakri \\ Universitas Lampung \\ e-mail: sutarto@fk.unila.ac.id
}

\begin{abstract}
Toddler children are a nutrition-prone group. so that if the nutritional intake is not as needed. Malnutrition in all its forms brings large direct and indirect costs to individuals. family and all countries. The purpose of this study is the relationship between the structure of the Lampung Province budget and the incidence of malnutrition and low birth weight during the last ten years.

This study method uses a method of analyzing literature and documents, by comparing the regional budget with the incidence of malnutrition and LBW and accompanied by a graph of linear equations.The effect of the financing provided by the Lampung Regional Government in the form of the annual budget and regional income in Lampung Province over the past 9 years against the incidence of malnutrition and LBW has an impact on the decline in incidence. Decrease in malnutrition 7 toddlers per 1,000,000 toddlers and LBW decreased by 4 per 100,000 from the incident with the addition of 1 million rupiah.
\end{abstract}

Keywords: budget; low birth weight; malnutrition

\section{Abstrak}

Anak balita merupakan kelompok rawan gizi. sehingga apabila asupan gizinya tidak sesuai kebutuhan. Malnutrisi dalam segala bentuknya membawa biaya langsung dan tidak langsung yang besar kepada individu. keluarga dan seluruh negara. Tujuan kajian ini adalah hubungan struktur Anggaran belanja Provinsi Lampung dengan kejadian gizi buruk dan berat bayi lahir rendah selama sepuluh tahun terakhir.

Metode kajian ini menggunakan metode analisa literature dan dokumen, dengan cara membandingkan antara anggaran belanja daerah dengan kejadian gizi buruk dan BBLR serta disertai dengan grafik persamaan linier. Pengaruh pembiayaan yang diberikan oleh Pemerintah Daerah Lampung dalam bentuk anggaran belanja dan pendapatan daerah tahunan di Provinsi Lampung selama 9 tahun terakhir terhadap kejadian gizi buruk dan BBLR memberikan dampak adanya penurunan kejadian. Penurunan gizi buruk 7 balita per 1.000.000 balita dan BBLR menurun sehanyak 4 pwe 100.000 dari kajadian dengan penambahan 1 juta rupiah. .

Kata Kunci : Rendah Anggran Belanja, Gizi Buruk

\section{INTRODUCTION}

Toddler children are a nutrition-prone group. so that if the nutritional intake is not as needed, it will affect its growth and development. Children under 5 years old (toddlers) have a high risk and should receive more attention. Because the higher the risk factors that apply to the child, the more likely the child will suffer from malnutrition. Poor nutrition toddlers who usually suffer from malnutrition also suffer from other diseases such as tuberculosis, cold cough and diarrhea. Malnutrition and malnutrition are 
complex problems and this problem is very important to overcome so as to reduce the morbidity and mortality of children under five (Sormin. 2015).

Malnutrition in all its forms brings large direct and indirect costs to individuals. family and all countries. The estimated impact on the global economy can be as high as US \$ 3.5 trillion per year. or US $\$ 500$ per individual (Beddington et al.. 2016). Estimates of the economic burden of public health problems that represent a large toll on infant survival and economic evaluation of effective interventions that improve survival are very important to guide health policy(Sicuri et al.. 2011). Urgent investment is needed in country-specific economic analysis of the costs and benefits associated with improving the quality and quantity of human resources (Beddington et al., 2016).

Low birth weight (LBW) is the birth weight of babies under 2,500 g regardless of gestational age. The costs associated with LBW in the South Mozambican Rural Area, Africa, that the additional costs for LBW were described in 2 cohorts of 3,322 infants, and mentioned the average cost per LBW and infants not LBW. Newborns who are not LBW with births treated less than 24 hours the average cost is US \$ 121. While the weight of the baby is born low, the average cost per LBW baby is US $\$ 425$, thus, the average cost per LBW baby is US \$ $546(425+121), 4.5$ times higher than the cost per non LBW baby (Sicuri et al., 2011). The high rate of LBW can affect the quality of human resources in the future. Therefore various efforts need to be made to reduce LBW rates (Nuryani \& Rahmawati, 2017).

Health financing is actually used to meet the needs of the community as much as possible. The health budget can be said as an instrument of the government in terms of fulfilling health rights for citizens. Normatively the health budget has been outlined by Law No. 36 of 2009 concerning health, in article 170 regarding funding it is said that the health budget is at least $10 \%$ of the APBD, and 2/3 of the funds are intended for public expenditure, specifically for poor women, and abandoned children (Ansar, 2017).

Based on the background above, the analysis will be continued on how the relationship between the structure of the Lampung Province budget and the incidence of malnutrition and low birth weight during the last ten years.

\section{METHOD}

This study uses a method of analyzing literature and documents that are already available, then connects the data of the Regional Budget and Regional Revenue (APBD) of Lampung in the health sector with the activity of decreasing poor nutrition and low birth weight (LBW) over the past 9 years. Furthermore, analysis uses linear functions to get the equation of the study model line and use articles that have been published in the last 5 years. The ABPD data in the Lampung Province health sector was obtained from the Regional Planning Management Agency (Bappeda) of Lampung Province in 20112018 and the data on the incidence of malnutrition - LBW was obtained from Lampung province health profile documents stored in the Lampung Provincial Health Office web site. The study carried out descriptive and analytical statistics on multivariate regression models. The method used is by comparing the regional budget with the incidence of malnutrition and LBW and accompanied by a graph of linear equations.

\section{FINDING AND DISCUSSION}

Under Law No. 23 of 2014 concerning Regional Government, gives authority to Regional Governments to regulate and manage their own government affairs according to the principle of 
autonomy and co-administration which are directed at accelerating the realization of public welfare through improving services, empowerment and the role of the community. Besides that, through autonomy, the regions are expected to be able to increase regional competitiveness by taking into account the principles of democracy, equity, justice and distinctiveness of a region within the Unitary State of the Republic of Indonesia.

Based on these laws, the Lampung Provincial Government, through its expenditure budget structure for the past 9 years (2011-2018), is seen increasing every year, and especially in the health budget. This budget data comes from the recapitulation of the Lampung Province Regional Planning Agency documents (BAPPEDA Prov. Lampung, 2019). In graph 1, the description of the budget structure shows that the increase has occurred since 2016, from 350 million to almost 600 million, this condition is seen, the Regional Government of Lampung Province is very concerned about development in the health sector. Health financing in this era of decentralization is highly dependent on regional commitments, particularly on government-funded financing. The health financing system in the regions needs to be developed so that the main issues in regional health financing, namely mobilization, allocation, and financing efficiency can be carried out well, so as to ensure equitable distribution, quality and balance of regional health development. (Sitorus \& Nurwahyuni, 2017).

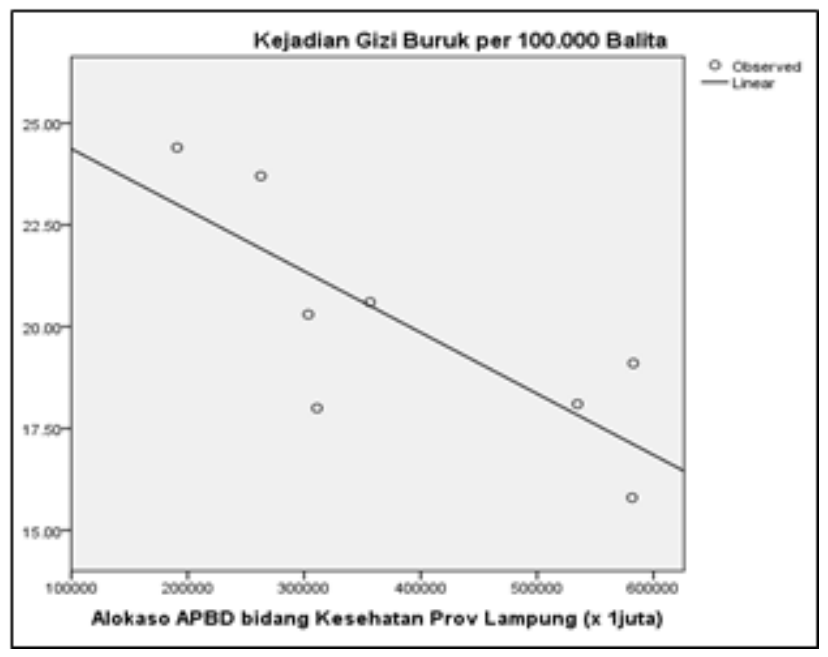

Graph 3. Structure of Angagran Expenditure is associated with the incidence of Malnutrition in Lampung Province 2011-2018. Malnutrition is an indicator of the success of the community nutrition improvement program. The funding in this sector is very much sourced both from the local government and from community self-help through the provision of supplementary food (PMT) which is carried out by health cadres at the Posyandu. LBW is an indicator of maternal health services that have been given to the community from the start of the first month's pregnancy procession to childbirth. LBW is also related to maternal nutritional status.

Data on the incidence of malnutrition which is the material of this analysis is based on the Lampung Province Health Profile documents. The incidence of malnutrition in the province over the past 10 years (2011-2019) has seen a decline. The line equation obtained is $y=25,873-0,793[\mathrm{x} 1]+\mathrm{e}$. This malnutrition line equation illustrates the incidence of malnutrition in a linear manner will reduce malnutrition by 7 per 1,000,000 toddlers every time there is an additional health budget of 1 billion. But this analysis has not been able to explain in detail according to the type of expenditure related to special expenditure related to activities to reduce malnutrition. This analysis will be better if supported by budget data by type. 
The operational expenditure component of the local government is at most compensation for employees around $49.2 \%-60.14 \%$, in the form of components in the form of salaries, honorariums, health insurance and other costs related to employees. Furthermore, the remainder is for material and service expenditures, consisting of drug expenditures, Travel and Accommodation expenditures, and other materials and services such as shopping for equipment, consulting services(Sitorus \& Nurwahyuni, 2017). And this condition is generally the same in the employee expenditure component with more percentage with restrictions on a certain percentage. This condition is aided by community resources, family income can affect the nutritional status of children under five, if a family has a large and sufficient income to meet the nutritional needs of family members, the nutritional needs of infants will be guaranteed(Mulazimah, 2017)

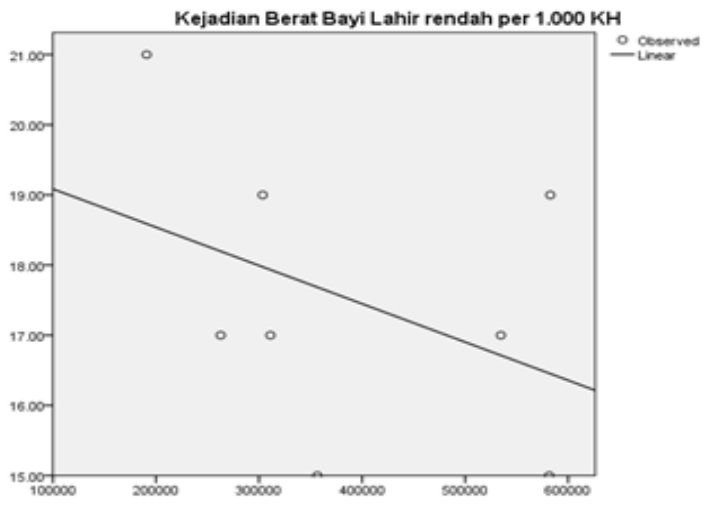

The incidence of low birth weight (LBW) in the Province for the last 9 years (2011-2018) shows a decrease. The line equation obtained is $\mathrm{y}=19,630-0,405(\mathrm{x} 1)+\mathrm{e}$. According to the linear LBW equation the LBW will decrease by 4 per 100,000 live births if there is an additional budget of 1 billion. LBW events are closely related to maternal health services produced by health workers. Antenatal care is a health service for pregnant women and their fetuses by professionals who cover pregnancy examinations with a standard of service at least 4 times during pregnancy, namely 1 time in the first trimester, 1 time in the second trimester and 2 times in the third trimester. Antenatal examination in pregnant women can detect abnormalities as early as possible so that the mother is expected to be able to care for herself during pregnancy and prepare for delivery The importance of this antenatal service is because each pregnancy can develop into problems or complications at any time, and the possibility of LBW. So that pregnant women need monitoring during their pregnancy(Andriani, Edison \& Lili, 2014). The frequency of antenatal care for women with pregnancy complications should be done at least once a month to obstetric and gynecology specialists. The cost of antenatal care to obstetricians and gynecologists is very expensive so that these costs cannot be reached by all pregnant women, especially in rural / poor communities (Narsih, Zakiyyah, \& Ernawati, 2016)

\section{CONCLUSION}

The effect of the financing provided by the Lampung Regional Government in the form of the annual budget and regional income in Lampung Province over the past 9 years against the incidence of malnutrition and LBW has an impact on the decline in incidence. Decrease in malnutrition 7 toddlers per $1,000,000$ toddlers and low birth weight decreased by 4 per 100,000 from the incident with the addition of 1 million rupiah 


\section{SUGGESTION}

The limitation in this study is that it cannot explain in detail the components of the budget provided by the Lampung Provincial Government, so that it cannot explain the direct relationship with the reduction of malnutrition and LBW. Expenditures directly related to the decline in the incidence include nutrition improvement programs and programs to improve maternal-child health services $(\mathrm{MCH})$.

\section{BIBLIOGRAPHY}

[1]. Andriani, Edison, G., \& Lili, A. (2014). Implementasi pelayanan ibu hamil (K4) oleh bidan berdasrkan SPM di Puskemas Singkawang. Jurnal Kesehatan Masyarakat, 8(1), 27-33.

[2]. Ansar. (2017). Problermatika Alokasi Dan Distribusi Anggaran Kesehatan Pada Dinas Kesehatan Propinsi Sulawesi Tengah Menurut Undang-Undang Kesehatan. Preventif, 8(1), 1-13.

[3]. BAPPEDA Prov. Lampung. (2019). Dokumen Rekapitulasi Angaran Belanja Pemerintah Provinsi Lampung. Bandar Lampung.

[4]. Beddington, J., Akinwumi, Kufuor, J., Arnold, T., Silva, G. da, Kalibata, A., ... Simmons, E. (2016). The Cost of Malnutrition: Why policy action is urgent. Global Panel on Agriculture and Food Systems for Nutrition., (3).

Retrieved from https://ble.lshtm.ac.uk/pluginfile.php/176270/mod_resource/content/0/Global Panel Cost Of Malnutrition.pdf

[5]. Mulazimah. (2017). Hubungan Pendapatan Keluarga Dengan Status Gizi Balita Desa Ngadiluwih Kecamatan Ngadiluwih Kabupaten Kediri. EFEKTOR, 1(1), 18-21. Retrieved from http://ojs.unpkediri.ac.id

[6]. Narsih, U., Zakiyyah, M., \& Ernawati, I. (2016). Faktor-Faktor yang Mempengaruhi Terjadinya Bayi dengan Berat Badan Lahir Rendah. Sain Med JURNAL KESEHATAN, 8(2), 83-88.

[7]. Nuryani, N., \& Rahmawati, R. (2017). Kejadian Berat Badan Lahir Rendah di Desa Tinelo Kabupaten Gorontalo dan Faktor yang Memengaruhinya. Jurnal Gizi Dan Pangan, 12(1), 49-54. https://doi.org/10.25182/jgp.2017.12.1.49

[8]. Sicuri, E., Bardají, A., Sigauque, B., Maixenchs, M., Nhacolo, A., Nhalungo, D., ... Menéndez, C. (2011). Costs associated with Low Birth Weight in a rural area of Southern Mozambique. PLoS ONE, 6(12). https://doi.org/10.1371/journal.pone.0028744

[9]. Sitorus, E., \& Nurwahyuni, A. (2017). Analisis Pembiayaan Kesehatan Bersumber Pemerintah di Kota Serang Tahun 2014 - 2016. Jurnal Kebijakan Kesehatan Indonesia, 6(3), 138. https://doi.org/10.22146/jkki.v6i3.29661

[10]. Sormin, T. (2015). Faktor-faktor yang berhubungan dengan status gizi anak balita di kecamatan Pekalongan Lampung Timur. Jurnal Keperawatan, XI(1), 33-40 